\title{
Intakes of energy, macronutrients and micronutrients of a population in severe food insecurity risk in Brazil
}

\author{
Stefanie Eugênia dos Anjos Coelho Kubo ${ }^{1,2, *}$, Teresa Helena Macedo da Costa ${ }^{1} \ddagger$ and \\ Muriel Bauermann Gubert ${ }^{1,2}$ \\ 'Department of Nutrition, Faculty of Health Science, University of Brasilia, Campus Darcy Ribeiro, Asa Norte, Brasilia, DF \\ 70910-900, Brazil: ${ }^{2}$ Center for Epidemiological Studies in Health and Nutrition, University of Brasília, Brasília, Brazil
}

Submitted 24 January 2019: Final revision received 4 June 2019: Accepted 8 July 2019: First published online 8 November 2019

\begin{abstract}
Objective: To analyse usual intakes of energy, macronutrients and micronutrients, and their percentage of inadequacy, in a Brazilian population at severe food insecurity (SFI) risk, determined from a predictive model using two national databases. Design: Cross-sectional study. Our study used a statistical model to predict SFI using the 2009 National Sample Household Survey, where the Brazilian Food Insecurity Scale measured SFI.

Setting: Brazil.

Participants: The model was applied in a probabilistic sample of 34003 Brazilians aged 10 years or older that participated in a national dietary survey during 2008-2009. The application of the model generated the probability of each individual being in SFI. The probability of SFI was grouped into quartiles (first quartile with the lowest SFI risk, fourth quartile with highest probability of SFI risk).

Results: The intakes of macro- and micronutrients were associated with SFI. The amount of energy and nutrients in the diet tended to be lower among individuals in the fourth quartile, with highest probability of SFI. The average intake of all studied minerals ( $\mathrm{Ca}, \mathrm{Fe}, \mathrm{Na}, \mathrm{Mg}$ ) was less in individuals in the fourth quartile. Only $\mathrm{Na}$ presented a higher percentage of inadequacy in the first quartile, the one with a lower chance of SFI.

Conclusions: The food intake of the Brazilian population at higher SFI risk is characterized by energy reduction, reduced consumption of macronutrients and high prevalence of inadequate micronutrient intakes, as well as a lower mean intakes, when compared with the first quartile with the lowest SFI risk.
\end{abstract}

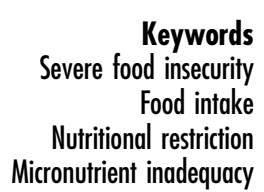

Food insecurity (FI) occurs when people do not have continuous access to food in sufficient quantity and quality to maintain their health. FI causes important changes in the individual's diet ${ }^{(1-4)}$. In FI the amount of food consumed is reduced and the quality of the diet is compromised, with lower consumption of fruits and vegetables, for example $^{(5,6)}$. FI also has negative health consequences, such as increasing the incidence of diseases associated with a poor diet, including obesity, diabetes, cardiovascular problems and other chronic non-communicable diseases in adults, as well as nutritional deficiencies, stunting, short stature and cognitive problems in children ${ }^{(7-12)}$.

$¥$ The original version of this article was submitted without one of the authors names given incorrectly. A notice detailing this has been published and the error rectified in the online PDF and HTML copies.
The Brazilian dietary pattern has been changing over the last decades and it is now characterized by a low-quality diet with increased consumption of ultra-processed foods, even among people living in poverty ${ }^{(13)}$. In households with FI families experience the so-called double burden of malnutrition, where nutritional deficiencies (malnutrition and micronutrient deficiency) coexist with overweight and other chronic non-communicable diseases ${ }^{(12,14)}$.

Over two billion people worldwide suffer from micronutrient deficiencies, also known as 'hidden hunger'(15). Vitamin and mineral deficiencies occur in cases of food deprivation, but also when the diet is monotonous and based on low-quality energy-dense foods ${ }^{(16,17)}$. Hidden hunger, as well as chronic hunger, have economic impacts as it negatively influences the individual's productivity, leading to persistent poverty and impacting the Gross Domestic Product of many developing countries ${ }^{(15,17)}$. 


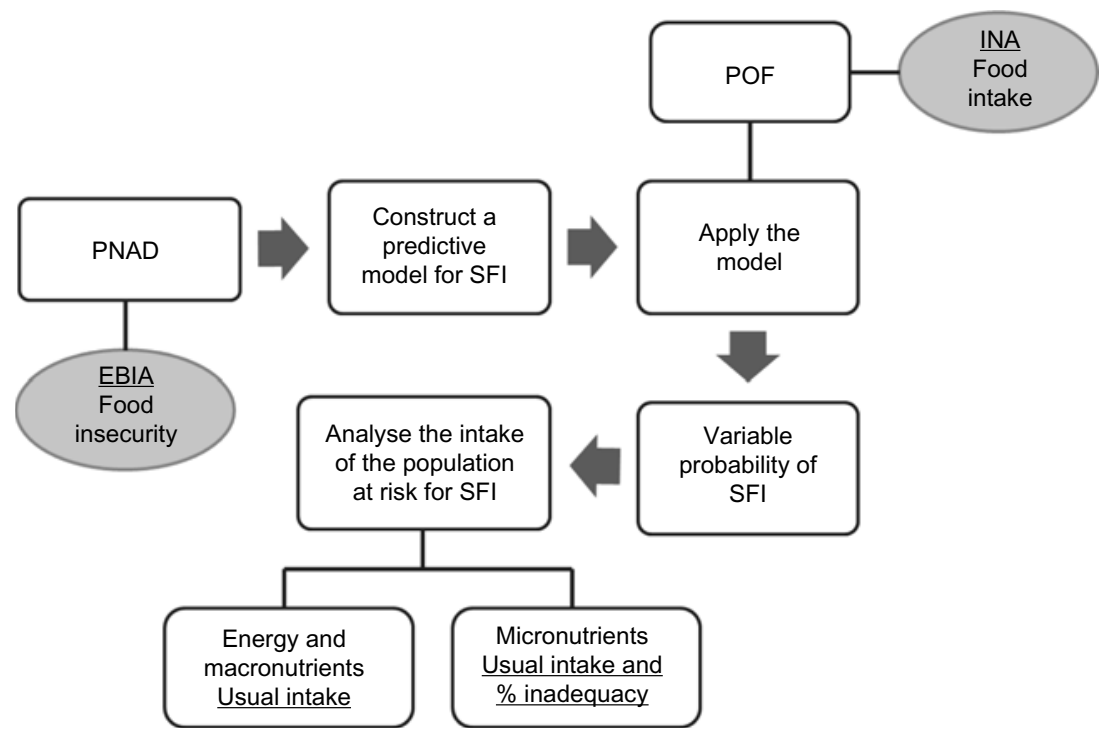

Fig. 1 Flowchart of steps for severe food insecurity (SFI) estimation and usual intake analysis (POF, Family Budget Survey 2008-09; INA, National Dietary Survey; PNAD, National Household Sample Survey 2009; EBIA, Brazilian Food Insecurity Scale)

In 2008-2009, the National Dietary Survey (INA) evaluated the Brazilian population's food consumption, collecting data on the food intake of 34003 individuals. At that time a high prevalence of micronutrient inadequacy was identified, meaning a high percentage of individuals with intake below the Estimated Average Requirement (EAR), especially for vitamins A, C, D and E, Ca and $\mathrm{Mg}^{(18)}$.

Despite the existence of data on the dietary profile of the Brazilian population in general, little is known about how FI can affect the quality of the diet regarding macro- and micronutrient intakes. Therefore, the aim of the present study was to analyse the usual intakes of energy, macronutrients, and micronutrients and their inadequacy in the Brazilian population in severe food insecurity (SFI) risk, determined from a predictive model that used two national databases.

\section{Methods}

\section{Databases used}

We used two surveys of the Brazilian population: the National Household Sample Survey (PNAD 2009) and the Family Budget Survey (POF 2008-09) ${ }^{(18,19)}$.

The PNAD 2009 interviewed 399387 individuals in 153837 households throughout Brazil. The survey evaluated household FI using the Brazilian Food Insecurity Scale (EBIA) ${ }^{(19)}$. Although there are more recent data for FI from PNAD (PNAD 2013), we chose to use the 2009 survey for its temporal proximity to the second survey used in the present study.

The POF 2008-09 is a survey with a representative population sample that aimed to evaluate consumption, expenditures, income and assets of Brazilians ${ }^{(18)}$. In the POF 2008-09 a sub-sample was selected to participate in the module that evaluated personal food consumption, the National Dietary Survey (INA). This module included the participation of 34003 individuals from 13569 households $(24.5 \%$ of the total households participating in the POF 2008-09). The POF 2008-09 did not have data on FI, only food consumption ${ }^{(18)}$.

The complex sample design of the two surveys are similar, based on census tracts and differing only in the number of stages (conglomerate or cluster). The complex sample design of POF 2008-09 was done in two stages and PNAD 2009 was done in three stages for sample selection. The Brazilian Institute of Geography and Statistics used the same census tracts for both surveys. The Institute makes use of a common sample infrastructure (cadaster and sample) in order to meet different surveys at the same time. The common sample, called the master sample, is a set of census tracts, which are considered the primary sampling units in the planning of all surveys carried by the Brazilian Institute of Geography and Statistics. Therefore, although the sample is not the same, the sampling process was similar, and the households had the same probability of being selected in both surveys. More detailed information on the process of sampling and data collection from the PNAD and the POF can be found elsewhere ${ }^{(18,19)}$.

The methodology to analyse SFI and food consumption was designed in three steps: (i) construction of a predictive model for SFI; (ii) estimation of the SFI probability for individuals participating in the INA/POF 2008-09; and (iii) analysis of the usual nutrient intakes and adequacies of vitamins and minerals according to SFI quartile (Fig. 1).

\section{Step 1: Creating a predictive model for severe food insecurity}

To make the analysis of food consumption by the population in SFI risk possible, a predictive statistical model for SFI was 
constructed using the PNAD 2009. The model was based on the methodology used by Gubert and co-workers in 2010 and 2017, which estimated household SFI for Brazilian municipalities using data from two national surveys ${ }^{(20,21)}$.

The first step was to select the potential predictive variables of SFI following two criteria: (i) variables should be previously associated with FI and (ii) they should exist in the two surveys used (PNAD and POF). These variables were identified in both surveys and recorded in identical categories in both the PNAD 2009 and the POF 2008-09.

The second step was the construction of a predictive model for SFI using the PNAD 2009. FI was measured by the EBIA ${ }^{(19)}$, which categorizes households with food security or with mild, moderate or severe FI. The unit of analysis was the household. The collective households were excluded (0.84\%; e.g. asylums, orphanages, convents, student republics, penitentiaries, military posts, hospitals), along with those whose head of household was under 18 years old $(2.81 \%)$ or indigenous $(2.74 \%)^{(21)}$. The remaining households were then classified dichotomously according to the presence of SFI. SFI was chosen because it is the most severe expression of FI, with the presence of hunger in the household, affecting even the children ${ }^{(19)}$.

For each variable selected, a bivariate analysis was performed to identify its association with SFI. Those with $P<0.20$ in the Wald test were selected to be tested in the multiple logistic regression model. The multiple regression model included all variables previously selected in the block. Then, the variables that had the lowest power of explanation (greater $P$ value) were removed one by one and checked to see if the exclusion of that variable had any positive effect on the explanatory power of the model. Those that did not help improve the model were excluded. The variables that made up the final model are presented in the online supplementary material, Supplemental File S1.

The final model was evaluated using Nagelkerke's pseudo $R^{2}$ test, which analyses the variance explained by the model, and the receiver-operating characteristic curve that evaluates its overall performance. The results are presented in the online supplementary material, Supplemental File $\mathrm{S} 2^{(22,23)}$

\section{Step 2: Estimating severe food insecurity for} individuals participating in the INA/POF 2008-09

In step 2, variables already categorized congruously in the constructed model were selected in the POF 2008-09 database. Like in the PNAD 2009, we excluded collective households, as well as those with head of household under 18 years of age or indigenous ${ }^{(20,21)}$.

The equation of the model was then applied to the POF 2008-09 data set. The result was a variable expressing the probability of the household being in SFI that varied from 0 to 1 . Then the household SFI probability was attributed to each individual living there. We generated the probability of SFI for 33714 individuals participating in the INA module. A total of 289 individuals were excluded because their household SFI risk probability was not possible to estimate due to missing information, or they fit the exclusion criteria. The SFI risk variable was grouped into quartiles. The analysis of food consumption compares the individuals with the lowest probabilities of SFI (first quartile, Q1) with those with the highest probabilities of experiencing SFI (fourth quartile, Q4).

For modelling and statistical analysis, we used the statistical software packages $\mathrm{R}$ version 3.2 .3 and IBM SPSS Statistics version 21, always considering the complex sample design of the PNAD and the POF.

\section{Step 3: Analysing usual intakes of nutrients and vitamin and mineral inadequacy}

At this stage, all individuals had already been assigned their SFI risk. In the INA, personal food consumption data were obtained through dietary records applied for each resident over 10 years old on two non-consecutive days. Individuals recorded all preparations and foods consumed within a $24 \mathrm{~h}$ time frame: type of food, time, quantities, how it was prepared and whether the meal was eaten inside or outside the home.

In the end, the participants listed a total of 1121 foods, preparations and beverages ${ }^{(18)}$. The nutritional composition of these foods and preparations was calculated using the Nutrition Data System for Research (NDSR) dietary analysis program (Nutrition Coordinating Center, University of Minnesota, Minneapolis, MN, USA) and the Brazilian Food Composition Table. A reference table of nutritional composition and referred measurements was built for all foods mentioned in the POF 2008-09 ${ }^{(24,25)}$. The study did not consider nutrients from dietary supplements.

To calculate the usual intakes (means and their standard errors) and the prevalence of nutritional inadequacies we used the method developed by the US National Cancer Institute $(\mathrm{NCI})^{(26)}$. The NCI method is a two-part mixed modelling process: the first part estimates the probability of consuming a food using logistic regression, and the second estimates the amount consumed daily using linear regression. In this work only nutrients were analysed, not foods; so only the second part of the model was used, since the nutrient intake is frequent. The generated estimation is then transformed by Box-Cox for normality and then reverted back to the original scale. This method considers the person-specific random effects, the probability of consuming the food/nutrient on a given day and the amount usually consumed per day ${ }^{(26)}$.

We used the MIXTRAN and DISTRIB macros developed by the NCI to estimate the percentiles of usual intake. The first macro transforms the data and adjusts the model, then DISTRIB uses the parameters previously estimated by MIXTRAN to determine the usual intake or percentage of inadequate intake through a simulation ${ }^{(27)}$. 
The NCI model was developed for simple random samples. In order to use the NCI method in a complex sample like INA, an additional programming was necessary. We used the balanced repeated replication (BRR) - Fay method - to calculate the standard errors considering the variability between the sub-samples (or replicate estimates). BRR is a method to estimate the variance used specifically in cases that have two primary sampling units per stratum. Since the INA has more than two primary sampling units per stratum, it was necessary to randomly group the primary sampling units of each stratum into two groups and then apply the BRR method; this procedure is called the grouped balanced half-sample (GBHS) method ${ }^{(27)}$.

Two non-consecutive daily food records were used to obtain the usual intake, which corresponds to the average long-term nutrient intake ${ }^{(26)}$. The models took into consideration the quartile of SFI probability in which the individual fit by sex and age group. We analysed the usual intake of energy, carbohydrates, fibres, proteins and total lipids. We also calculated the $95 \%$ CI for the mean intake in grams, in the first and fourth quartiles of SFI, to verify if the difference in intake between quartiles was significant (data available in the online supplementary material, Supplemental File S3). For macronutrients and fibres, the results are described by life-cycle stage (adolescents 10-18 years, adults 19-59 years, elderly aged 60 years or older).

To analyse micronutrient intakes, we selected those with the highest percentage of inadequacy for the Brazilian population and those that are most relevant for public health $^{(18)}$. Vitamins A, C, D and E, along with Ca, $\mathrm{Fe}, \mathrm{Mg}$ and $\mathrm{Na}$ were analysed.

The prevalence of inadequacy was calculated according to sex and age group using the EAR of each nutrient ${ }^{(28,29)}$. This inadequacy can be interpreted as the proportion of individuals with intake lower than the EAR recommendation. For $\mathrm{Na}$, the cut-off point was the Tolerable Upper Intake Level (UL), since the intake of this micronutrient in Brazil is considered high ${ }^{(30)}$. Intake values above the UL were considered excessive, and therefore inadequate. The results were described for each of the sex and age groups according to EAR values for each nutrient ${ }^{(28,29)}$.

For $\mathrm{Fe}$, the inadequacy was estimated using the probability approach method, since the requirement distribution of this micronutrient in women of reproductive age is not symmetric and does not allow use of the EAR as a cut-off point ${ }^{(31)}$. The method was used to estimate the usual intake and the percentage of inadequacy for both sexes, to allow comparisons. Percentiles of the usual Fe intake distribution were estimated (10, 15, 25, 50, 75 and 90). For each percentile, a probability of Fe inadequacy was associated with the Fe requirement intervals by sex and age group. The risk of inadequacy was calculated taking account of the number of individuals in each group, their intake and probability of inadequacy. The prevalence of Fe inadequacy was obtained by adding the percentage of individuals with inadequacy in each percentile. The probability approach method does not allow estimation of the standard error of the Fe inadequacies ${ }^{(31)}$.

Usual intakes of energy, macro- and micronutrients, as well as the micronutrient inadequacies, were analysed in the statistical software package SAS version 9.4.

\section{Results}

The usual intake of energy was significantly lower in Q4 (the one with higher SFI risk), except for women aged over 60 years. Energy intake was lower among men, especially adolescents. Male and female adolescents in Q4 consumed 16.7 and $19.4 \%$ less energy, respectively, than those in Q1 (Table 1).

The reduction in protein intake in Q4 ranged from $7 \cdot 1$ to $14.3 \%$ when compared with Q1. In the same way as with energy, there were significant differences in protein intake, except among elderly women. Usual intakes of carbohydrates and lipids were also lower among individuals with a greater risk of SFI (Q4), regardless of sex and age group. While the decrease in carbohydrate intake was up to $15.5 \%$, for lipids this reduction reached $32.6 \%$ among male adolescents in Q4. There were no significant differences in the usual fibre intake, since there was a low intake in both quartiles (Table 1).

In general, the prevalence of inadequate intake of micronutrients was high in both quartiles. However, in Q4 the prevalence of inadequacy was greater, and the usual micronutrient intake amounts were lower than in Q1 (Table 2 and Table 3).

High prevalence of inadequacy (above $90 \%$ ) of vitamin A was observed among individuals at higher risk of SFI. Vitamin C also had higher percentages of inadequacy in Q4, reaching $81 \%$ among men over 70 years of age. Almost $100 \%$ of individuals in both groups had inadequate intakes of vitamins $\mathrm{D}$ and $\mathrm{E}$. In addition to the high percentage of inadequacy, a lower usual intake was also observed in Q4. The usual intake of vitamin C in Q4 was almost half of what was consumed in Q1. Furthermore, the usual intakes of vitamins $\mathrm{D}$ and $\mathrm{E}$ were lower in the quartile with more SFI, reaching a reduction of $1.2 \mu \mathrm{g}$ for vitamin $\mathrm{D}$ among male adolescents in Q4 (Table 2).

The usual intake of all studied minerals ( $\mathrm{Ca}, \mathrm{Fe}, \mathrm{Na}$ and $\mathrm{Mg}$ ) was lower in Q4 across all age and sex groups. The prevalence of inadequate Fe intake was greater for females in both quartiles. The greatest prevalence of inadequacy of Fe (above $40 \%$ ) was observed among menstruating women in Q4 (Table 3). The highest prevalence of $\mathrm{Mg}$ inadequacy occurred among adolescents (14-18 years) and the elderly (over 70 years; Table 3 ).

Regarding $\mathrm{Na}$, unlike the other minerals and vitamins studied, intake above the UL was more prevalent in Q1, the one with a lower risk of SFI. However, in both quartiles the usual intake of this nutrient exceeded the UL for daily intake of $\mathrm{Na}$ (2300 mg/d; Table 3). 
Table 1 Mean usual intakes of energy and nutrients by sex, age group and quartile of probability of severe food insecurity. Brazil, 2008-2009

\begin{tabular}{|c|c|c|c|c|c|c|c|}
\hline \multirow[b]{2}{*}{ Nutrient/sex/age group } & \multicolumn{3}{|c|}{ Q1 } & \multicolumn{3}{|c|}{ Q4 } & \multirow[b]{2}{*}{ Difference between Q1 and Q4 (\%) } \\
\hline & $n$ & Usual intake & SE & $n$ & Usual intake & SE & \\
\hline \multicolumn{8}{|l|}{ Energy (kcal)* } \\
\hline \multicolumn{8}{|l|}{ Female } \\
\hline 10-18 years & 548 & $2097 \cdot 2$ & $52 \cdot 9$ & 1145 & $1747 \cdot 3$ & $28 \cdot 0$ & $-16 \cdot 7$ \\
\hline $19-59$ years & 3080 & $1786 \cdot 3$ & $14 \cdot 1$ & 2556 & 1591.7 & 18.5 & $-10 \cdot 9$ \\
\hline$\geq 60$ years & 630 & $1580 \cdot 8$ & $42 \cdot 8$ & 444 & 1454.7 & $25 \cdot 1$ & $-8.0 \dagger$ \\
\hline \multicolumn{8}{|l|}{ Male } \\
\hline $10-18$ years & 539 & $2278 \cdot 6$ & $7 \cdot 0$ & 1214 & $1837 \cdot 2$ & $50 \cdot 0$ & $-19 \cdot 4$ \\
\hline $19-59$ years & 2885 & 2241.6 & 23.5 & 2250 & 1969.9 & 31.4 & $-12 \cdot 1$ \\
\hline$\geq 60$ years & 570 & $1987 \cdot 3$ & $41 \cdot 1$ & 330 & $1729 \cdot 8$ & $39 \cdot 3$ & $-13 \cdot 0$ \\
\hline \multicolumn{8}{|l|}{ Proteins $(\mathrm{g})$} \\
\hline \multicolumn{8}{|l|}{ Female } \\
\hline $10-18$ years & 548 & $79 \cdot 1$ & $2 \cdot 2$ & 1145 & $70 \cdot 1$ & 1.3 & -11.4 \\
\hline $19-59$ years & 3080 & $74 \cdot 2$ & 0.4 & 2556 & $67 \cdot 7$ & $1 \cdot 1$ & $-8 \cdot 8$ \\
\hline$\geq 60$ years & 630 & $67 \cdot 4$ & 1.6 & 444 & 67.5 & 3.0 & $+0 \cdot 1 \dagger$ \\
\hline \multicolumn{8}{|l|}{ Māe } \\
\hline $10-18$ years & 539 & $87 \cdot 3$ & $2 \cdot 3$ & 1214 & 74.8 & 1.7 & -14.3 \\
\hline $19-59$ years & 2885 & 94.8 & 0.5 & 2250 & 88.1 & 1.4 & $-7 \cdot 1$ \\
\hline$\geq 60$ years & 570 & $87 \cdot 2$ & 1.9 & 330 & $78 \cdot 2$ & $2 \cdot 1$ & $-10 \cdot 3$ \\
\hline \multicolumn{8}{|l|}{ Carbohydrates (g) } \\
\hline \multicolumn{8}{|l|}{ Female } \\
\hline 10-18 years & 548 & $292 \cdot 6$ & $6 \cdot 3$ & 1145 & 249.6 & $5 \cdot 8$ & $-14 \cdot 7$ \\
\hline $19-50$ years & 3080 & $244 \cdot 1$ & 2.4 & 2556 & $225 \cdot 5$ & $2 \cdot 8$ & $-7 \cdot 6$ \\
\hline$\geq 60$ years & 630 & $220 \cdot 7$ & $5 \cdot 6$ & 444 & 203.5 & 2.5 & $-7 \cdot 8$ \\
\hline \multicolumn{8}{|l|}{ Male } \\
\hline 10-18 years & 539 & $313 \cdot 8$ & $6 \cdot 2$ & 1214 & 265.2 & 7.4 & $-15 \cdot 5$ \\
\hline $19-50$ years & 2885 & 298.8 & $3 \cdot 6$ & 2250 & 273.9 & $5 \cdot 1$ & $-8 \cdot 3$ \\
\hline$\geq 60$ years & 570 & $267 \cdot 4$ & $6 \cdot 3$ & 330 & $237 \cdot 0$ & 4.5 & -11.4 \\
\hline \multicolumn{8}{|l|}{ Total lipids (g) } \\
\hline \multicolumn{8}{|l|}{ Female } \\
\hline $10-18$ years & 548 & $69 \cdot 6$ & $2 \cdot 1$ & 1145 & $51 \cdot 2$ & 0.8 & $-26 \cdot 4$ \\
\hline $19-59$ years & 3080 & 57.5 & 0.8 & 2556 & $45 \cdot 3$ & 0.6 & $-21 \cdot 2$ \\
\hline$\geq 60$ years & 630 & $49 \cdot 2$ & 1.7 & 444 & 39.9 & 1.5 & -18.9 \\
\hline \multicolumn{8}{|l|}{ Male } \\
\hline $10-18$ years & 539 & $75 \cdot 4$ & $2 \cdot 1$ & 1214 & $50 \cdot 8$ & 1.8 & $-32 \cdot 6$ \\
\hline $19-59$ years & 2885 & 71.3 & 0.9 & 2250 & 53.4 & 0.9 & $-25 \cdot 1$ \\
\hline$\geq 60$ years & 570 & $61 \cdot 3$ & 1.3 & 330 & $48 \cdot 0$ & 1.3 & $-21 \cdot 7$ \\
\hline \multicolumn{8}{|l|}{ Fibre $(g)$} \\
\hline \multicolumn{8}{|l|}{ Female } \\
\hline 10-18 years & 548 & $17 \cdot 5$ & 0.5 & 1145 & $18 \cdot 3$ & 0.3 & $+4.6 \dagger$ \\
\hline $19-59$ years & 3080 & $17 \cdot 8$ & 0.2 & 2556 & $17 \cdot 6$ & 0.2 & $-1.1 \dagger$ \\
\hline \multirow{2}{*}{\multicolumn{8}{|c|}{ Male }} \\
\hline & & & & & & & \\
\hline $10-18$ years & 539 & $20 \cdot 3$ & 0.8 & 1214 & $20 \cdot 2$ & 0.4 & $-0.5 \dagger$ \\
\hline $19-59$ years & 2885 & 21.9 & 0.3 & 2250 & $22 \cdot 8$ & 0.3 & $+4.1 \dagger$ \\
\hline$\geq 60$ years & 570 & $21 \cdot 8$ & $1 \cdot 2$ & 330 & $20 \cdot 3$ & 0.5 & $-6.9 \dagger$ \\
\hline
\end{tabular}

Q1, quartile 1 (lowest probability of severe food insecurity); Q4, quartile 4 (highest probability of severe food insecurity).

The confidence intervals are shown in the online supplementary material, Supplemental File S3.

*To convert to kJ, multiply kcal values by 4.184 .

†Difference between the mean consumption of Q1 and Q4 was not significant according to $95 \% \mathrm{Cl}$.

\section{Discussion}

Our results revealed that intakes of macro- and micronutrients were associated with SFI. The amount of energy and nutrients in the diet tended to be lower among individuals in the quartile with highest probability of SFI (Q4).

The average energy intake of the Brazilian population is approximately $7112-9623 \mathrm{~kJ} / \mathrm{d}(1700-2300 \mathrm{kcal} / \mathrm{d})$, depending on sex and age group ${ }^{(18)}$. In our study, the usual energy intake among the individuals with the greatest risk of SFI (Q4) was about $6066-8158 \mathrm{~kJ} / \mathrm{d}(1450-1950 \mathrm{kcal} / \mathrm{d})$ across age and sex groups, indicating lower energy intake when compared with the average Brazilian. In addition to energy, we found important reductions in protein and lipid intakes among individuals in Q4, as well as low fibre intake in both quartiles. Frozi et al. point out that smaller portion sizes and reduced fruit and vegetable consumption are usually adopted as coping strategies by families in extreme poverty ${ }^{(32)}$. In other studies, although they did not associate energy or macronutrient intakes with FI, they indicated a compromised diet quality, with the substitution of healthy foods by other energy-dense foods which are high in sugar 
Table 2 Usual mean intakes of vitamins, and percentage of vitamin inadequacy (\%l), by sex, age group and quartile of probability of severe food insecurity. Brazil, 2008/2009*

\begin{tabular}{|c|c|c|c|c|c|c|c|c|}
\hline \multirow[b]{2}{*}{ Vitamin/sex/age group } & \multicolumn{4}{|c|}{ Q1 } & \multicolumn{4}{|c|}{ Quartile 4} \\
\hline & $n$ & Usual intake & SE & $\% l$ & $n$ & Usual intake & SE & $\%$ \\
\hline \multicolumn{9}{|l|}{ Vitamin $A(\mu \mathrm{g})$} \\
\hline \multicolumn{9}{|l|}{ Female } \\
\hline $10-13$ years & 211 & $416 \cdot 0$ & $21 \cdot 6$ & 62 & 580 & $199 \cdot 7$ & $8 \cdot 3$ & 93 \\
\hline $14-18$ years & 337 & 333.0 & $18 \cdot 0$ & 81 & 565 & 229.1 & 12.5 & 93 \\
\hline $19-50$ years & 2538 & $312 \cdot 6$ & $10 \cdot 6$ & 85 & 2201 & 204.0 & 8.0 & 96 \\
\hline $51-70$ years & 946 & $286 \cdot 1$ & 21.9 & 88 & 612 & 194.9 & 14.4 & 96 \\
\hline$>70$ years & 226 & 285.8 & $9 \cdot 0$ & 88 & 187 & $207 \cdot 1$ & $16 \cdot 4$ & 95 \\
\hline \multicolumn{9}{|l|}{ Male } \\
\hline $10-13$ years & 205 & $385 \cdot 3$ & $20 \cdot 8$ & 70 & 591 & $197 \cdot 7$ & $13 \cdot 1$ & 94 \\
\hline $14-18$ years & 334 & $350 \cdot 7$ & $12 \cdot 6$ & 89 & 623 & $226 \cdot 3$ & $12 \cdot 3$ & 93 \\
\hline $19-50$ years & 2395 & 337.6 & $12 \cdot 9$ & 90 & 1969 & 211.3 & $10 \cdot 4$ & 98 \\
\hline $51-70$ years & 858 & 287.6 & 12.5 & 94 & 487 & $170 \cdot 6$ & 9.6 & 99 \\
\hline$>70$ years & 202 & $297 \cdot 1$ & $28 \cdot 2$ & 93 & 114 & 188.9 & $19 \cdot 0$ & 99 \\
\hline \multicolumn{9}{|l|}{ Vitamin C (mg) } \\
\hline \multicolumn{9}{|l|}{ Female } \\
\hline $10-13$ years & 211 & 141.4 & $10 \cdot 8$ & 20 & 580 & 78.5 & $8 \cdot 0$ & 41 \\
\hline $14-18$ years & 401 & $156 \cdot 2$ & $10 \cdot 8$ & 27 & 651 & 94.2 & 8.2 & 47 \\
\hline $19-50$ years & 2474 & $157 \cdot 1$ & 7.6 & 28 & 2114 & $86 \cdot 2$ & $5 \cdot 1$ & 53 \\
\hline $51-70$ years & 946 & $166 \cdot 4$ & $11 \cdot 0$ & 25 & 611 & $86 \cdot 4$ & $11 \cdot 6$ & 53 \\
\hline$>70$ years & 226 & $166 \cdot 7$ & $10 \cdot 3$ & 25 & 186 & $81 \cdot 2$ & $10 \cdot 0$ & 55 \\
\hline \multicolumn{9}{|l|}{ Male } \\
\hline $10-13$ years & 205 & 154.6 & 11.9 & 18 & 591 & 93.0 & $15 \cdot 9$ & 34 \\
\hline $14-18$ years & 383 & $127 \cdot 1$ & $6 \cdot 3$ & 39 & 714 & $84 \cdot 8$ & $5 \cdot 7$ & 56 \\
\hline $19-50$ years & 2346 & $154 \cdot 7$ & $7 \cdot 7$ & 36 & 1875 & 85.4 & 2.9 & 62 \\
\hline $51-70$ years & 858 & $166 \cdot 2$ & $7 \cdot 0$ & 33 & 496 & $66 \cdot 6$ & $9 \cdot 7$ & 71 \\
\hline$>70$ years & 202 & $210 \cdot 5$ & $10 \cdot 7$ & 24 & 114 & $48 \cdot 7$ & $6 \cdot 2$ & 81 \\
\hline \multicolumn{9}{|l|}{ Vitamin D $(\mu \mathrm{g})$} \\
\hline \multicolumn{9}{|l|}{ Female } \\
\hline 10-18 years & 548 & $3 \cdot 6$ & $0 \cdot 1$ & 98 & 1145 & $2 \cdot 8$ & 0.1 & 99 \\
\hline $19-50$ years & 2538 & $3 \cdot 2$ & 0.1 & 99 & 2201 & $2 \cdot 7$ & 0.0 & 99 \\
\hline $51-70$ years & 946 & $3 \cdot 0$ & 0.1 & 99 & 612 & $2 \cdot 6$ & 0.2 & 99 \\
\hline \multirow{2}{*}{\multicolumn{9}{|c|}{ Male }} \\
\hline & & & & & & & & \\
\hline 10-18 years & 539 & $4 \cdot 1$ & 0.1 & 97 & 1214 & $2 \cdot 8$ & 0.1 & 99 \\
\hline $19-50$ years & 2395 & 3.6 & 0.1 & 98 & 1969 & $3 \cdot 4$ & 0.1 & 98 \\
\hline $51-70$ years & 858 & 3.5 & 0.1 & 98 & 497 & 2.9 & 0.2 & 99 \\
\hline$>70$ years & 202 & $3 \cdot 7$ & 0.1 & 98 & 114 & 2.5 & 0.4 & 100 \\
\hline \multicolumn{9}{|l|}{ Vitamin E (mg) } \\
\hline \multicolumn{9}{|l|}{ Female } \\
\hline $10-13$ years & 211 & $4 \cdot 3$ & 0.2 & 99 & 580 & 3.4 & 0.1 & 100 \\
\hline $14-18$ years & 337 & $4 \cdot 0$ & 0.1 & 100 & 565 & $3 \cdot 7$ & 0.1 & 100 \\
\hline $19-50$ years & 2538 & $4 \cdot 0$ & 0.0 & 100 & 2201 & 3.4 & 0.0 & 100 \\
\hline $51-70$ years & 946 & 4.0 & 0.1 & 100 & 612 & 3.4 & 0.0 & 100 \\
\hline$>70$ years & 226 & $3 \cdot 8$ & 0.1 & 100 & 187 & $3 \cdot 0$ & 0.2 & 100 \\
\hline \multicolumn{9}{|l|}{ Male } \\
\hline $10-13$ years & 205 & $4 \cdot 2$ & 0.4 & 99 & 591 & $3 \cdot 6$ & 0.1 & 100 \\
\hline $14-18$ years & 334 & 4.6 & 0.3 & 100 & 623 & 4.0 & 0.1 & 100 \\
\hline $19-50$ years & 2395 & $5 \cdot 0$ & 0.0 & 100 & 1969 & 4.3 & 0.0 & 100 \\
\hline $51-70$ years & 858 & 4.8 & 0.1 & 100 & 497 & 3.8 & 0.1 & 100 \\
\hline$>70$ years & 202 & 4.6 & 0.1 & 100 & 114 & $3 \cdot 2$ & 0.3 & 100 \\
\hline
\end{tabular}

Q1, quartile 1 (lowest probability of severe food insecurity); Q4, quartile 4 (highest probability of severe food insecurity).

*Women who were pregnant or nursing were not included in the analysis.

and $\mathrm{fat}^{(3,5)}$. Consumption of these energy-rich and nutrientpoor foods, either because of their low cost ${ }^{(33)}$ or because of the unavailability of healthy foods nearby (i.e. food deserts $)^{(34,35)}$, can compensate in terms of kilojoules for the quantitative reduction in their diet and can contribute to increase obesity in this population ${ }^{(36)}$. Therefore, discussions about the diet of people at risk for SFI must go beyond simply assessing energy intake.
Throughout the world, the micronutrients with the lowest adequate intake levels are $\mathrm{Ca}, \mathrm{Fe}$, vitamin $\mathrm{A}$ and $\mathrm{Zn}^{(37)}$. In Brazil, these same nutrients present high percentages of inadequate intake ${ }^{(18)}$. Our study also found important prevalences of inadequacy in both quartiles of SFI probability. However, the reduction in intake was even more pronounced in Q4, especially for vitamins A and C, Ca and Fe. The inadequacy of vitamin A is closely related to 
Table 3 Mean usual intakes of minerals, and percentage of inadequacy (\%l) of calcium, iron, sodium and magnesium, by sex, age group and quartile of probability of severe food insecurity. Brazil, 2008/2009*

\begin{tabular}{|c|c|c|c|c|c|c|c|c|}
\hline \multirow[b]{2}{*}{ Mineral/sex/age group } & \multicolumn{4}{|c|}{ Q1 } & \multicolumn{4}{|c|}{ Q4 } \\
\hline & $n$ & Usual intake & SE & $\%$ & $n$ & Usual intake & SE & $\%$ \\
\hline \multicolumn{9}{|l|}{$\mathrm{Ca}(\mathrm{mg})$} \\
\hline \multicolumn{9}{|l|}{ Female } \\
\hline 10-18 years & 548 & 651.8 & 21.6 & 92 & 1145 & 411.2 & 8.9 & 99 \\
\hline $19-50$ years & 2538 & 574.1 & 7.5 & 82 & 2201 & $366 \cdot 1$ & 4.9 & 97 \\
\hline $51-70$ years & 946 & 573.8 & $20 \cdot 3$ & 93 & 612 & 387.9 & 11.9 & 99 \\
\hline$>70$ years & 226 & $548 \cdot 1$ & 21.8 & 94 & 185 & 419.6 & 16.5 & 98 \\
\hline \multicolumn{9}{|l|}{ Male } \\
\hline $10-18$ years & 539 & 692.8 & $18 \cdot 1$ & 90 & 1214 & $410 \cdot 7$ & 8.5 & 99 \\
\hline $19-50$ years & 2395 & 653.6 & 4.5 & 74 & 1669 & 433.5 & 7.9 & 94 \\
\hline $51-70$ years & 858 & $620 \cdot 0$ & $20 \cdot 2$ & 78 & 497 & 412.9 & $24 \cdot 3$ & 95 \\
\hline$>70$ years & 202 & 628.0 & $20 \cdot 2$ & 90 & 114 & 409.6 & $36 \cdot 7$ & 98 \\
\hline \multicolumn{9}{|l|}{$\mathrm{Fe}(\mathrm{mg})$} \\
\hline \multicolumn{9}{|l|}{ Female } \\
\hline $10-13$ years & 211 & $12 \cdot 6$ & 0.4 & 4.4 & 580 & 9.5 & 0.3 & 14.9 \\
\hline $14-18$ years & 337 & 11.6 & 0.3 & $25 \cdot 0$ & 565 & $10 \cdot 1$ & 0.2 & $42 \cdot 2$ \\
\hline $19-50$ years & 2538 & $10 \cdot 6$ & 0.1 & 32.4 & 2201 & $9 \cdot 0$ & 0.1 & $40 \cdot 8$ \\
\hline $51-70$ years & 946 & $9 \cdot 6$ & 0.1 & $10 \cdot 1$ & 612 & $8 \cdot 7$ & 0.1 & 14.9 \\
\hline$>70$ years & 226 & $8 \cdot 7$ & 0.2 & $13 \cdot 6$ & 187 & 7.9 & 0.3 & $20 \cdot 1$ \\
\hline \multicolumn{9}{|l|}{ Male } \\
\hline $10-13$ years & 205 & $12 \cdot 3$ & 0.9 & 4.6 & 591 & $9 \cdot 7$ & 0.4 & $14 \cdot 7$ \\
\hline $14-18$ years & 334 & $14 \cdot 2$ & 0.4 & $8 \cdot 0$ & 623 & $10 \cdot 9$ & 0.3 & 24.5 \\
\hline $19-50$ years & 2395 & $13 . \overline{7}$ & 0.2 & 3.7 & 1969 & $11 \cdot 8$ & 0.1 & $7 \cdot 6$ \\
\hline $51-70$ years & 858 & $12 \cdot 6$ & 0.4 & $6 \cdot 0$ & 497 & $10 \cdot 6$ & 0.4 & $13 \cdot 2$ \\
\hline$>70$ years & 202 & $10 \cdot 7$ & 0.4 & $12 \cdot 4$ & 114 & 9.6 & 0.4 & $16 \cdot 4$ \\
\hline \multicolumn{9}{|l|}{$\mathrm{Na}(\mathrm{mg})$} \\
\hline \multicolumn{9}{|l|}{ Female } \\
\hline $10-13$ years & 211 & $3240 \cdot 6$ & 86.4 & 83 & 580 & $2727 \cdot 7$ & $94 \cdot 1$ & 68 \\
\hline $14-18$ years & 337 & $2820 \cdot 3$ & $138 \cdot 1$ & 71 & 565 & 2889.5 & $43 \cdot 7$ & 74 \\
\hline $19-50$ years & 2538 & 2847.1 & 22.0 & 62 & 2201 & 2669.4 & 27.9 & 61 \\
\hline $51-70$ years & 946 & $2750 \cdot 0$ & $48 \cdot 4$ & 65 & 612 & $2662 \cdot 1$ & 62.0 & 61 \\
\hline$>70$ years & 226 & 2687.6 & 79.8 & 63 & 187 & $2470 \cdot 1$ & $110 \cdot 8$ & 53 \\
\hline \multicolumn{9}{|l|}{ Male } \\
\hline 10-13 years & 205 & $3310 \cdot 1$ & $205 \cdot 7$ & 85 & 591 & $2861 \cdot 3$ & $96 \cdot 7$ & 73 \\
\hline $14-18$ years & 334 & $3702 \cdot 0$ & 130.5 & 91 & 623 & 3227.4 & $74 \cdot 1$ & 83 \\
\hline $19-50$ years & 2395 & $3675 \cdot 3$ & $16 \cdot 4$ & 90 & 1969 & 3412.5 & 46.9 & 85 \\
\hline $51-70$ years & 858 & $3524 \cdot 1$ & 61.9 & 87 & 497 & 3123.7 & $97 \cdot 2$ & 77 \\
\hline$>70$ years & 202 & $3152 \cdot 3$ & 95.7 & 79 & 114 & 2812.9 & 205.2 & 68 \\
\hline \multicolumn{9}{|l|}{$\mathrm{Mg}(\mathrm{mg})$} \\
\hline \multicolumn{9}{|l|}{ Female } \\
\hline $10-13$ years & 211 & 247.8 & $13 \cdot 1$ & 34 & 580 & 214.2 & $6 \cdot 6$ & 49 \\
\hline $14-18$ years & 337 & $222 \cdot 5$ & 3.5 & 84 & 565 & 217.8 & $3 \cdot 3$ & 85 \\
\hline $19-30$ years & 919 & 223.1 & 3.5 & 69 & 921 & $206 \cdot 6$ & $5 \cdot 7$ & 76 \\
\hline $31-50$ years & 1619 & 221.5 & $3 \cdot 1$ & 74 & 1280 & $205 \cdot 5$ & 4.5 & 80 \\
\hline $51-70$ years & 948 & $220 \cdot 1$ & 1.3 & 74 & 614 & 208.9 & 7.5 & 79 \\
\hline$>70$ years & 226 & $212 \cdot 8$ & 8.7 & 77 & 187 & 193.1 & 9.5 & 84 \\
\hline \multicolumn{9}{|l|}{ Male } \\
\hline $10-13$ years & 205 & 237.2 & $15 \cdot 7$ & 38 & 591 & $219 \cdot 1$ & $7 \cdot 2$ & 46 \\
\hline $14-18$ years & 334 & 268.6 & $3 \cdot 8$ & 78 & 623 & $242 \cdot 3$ & $3 . \overline{9}$ & 86 \\
\hline $19-30$ years & 931 & 273.0 & 3.9 & 75 & 916 & 274.8 & $7 \cdot 6$ & 75 \\
\hline $31-50$ years & 1464 & 278.2 & 2.4 & 79 & 1053 & $266 \cdot 1$ & 3.5 & 82 \\
\hline $51-70$ years & 858 & 275.8 & 3.5 & 79 & 497 & 239.6 & 8.8 & 89 \\
\hline$>70$ years & 202 & 252.4 & 8.3 & 85 & 114 & 224.4 & 13.6 & 92 \\
\hline
\end{tabular}

Q1, quartile 1 (lowest probability of severe food insecurity); Q4, quartile 4 (highest probability of severe food insecurity). *Women who were pregnant or nursing were not included in the analysis.

a low quality of diet, with insufficient consumption of vegetables, especially those with yellow/orange colour ${ }^{(18,38)}$. Vitamin C, especially, draws attention because the recommended intake should be easy to achieve through the consumption of citrus fruits that are abundant in Brazilian flora $^{(39)}$, for example the orange, which is one of the most consumed fruits in the country and has a low cost ${ }^{(18)}$. Apparently, even access to these foods is limited for those who have greater probabilities of experiencing SFI (Q4). Regarding $\mathrm{Fe}$, the problem was more prevalent in women of reproductive age in Q4. FI further exposes these women, who are already a risk group, to the development of Fe-deficiency anaemia ${ }^{(40)}$.

Vitamins D and E presented similar and high prevalences of inadequacy in both quartiles, which was expected because the INA had already demonstrated this 
phenomenon in the Brazilian population in general, reflecting the recent changes in Brazilians' diet ${ }^{(18)}$. What is striking in our study is the amount of these micronutrients ingested. Although the inadequacy of these two vitamins is generalized in both quartiles, Q4 had a much lower usual intake than Q1. In this case, in addition to the percentage of inadequacy, it is important to analyse the amount consumed, which is far less than the EAR reference value of $12 \mathrm{mg} / \mathrm{d}$ for vitamin $\mathrm{E}$ and $10 \mu \mathrm{g} / \mathrm{d}$ for vitamin $\mathrm{D}^{(28,29)}$. It should be noted that the consumption of vegetable oil (vitamin E) and sun exposure (vitamin D) contribute to the supply of these vitamins and there are analytical limitations in the measurement of the contribution of these sources in population studies ${ }^{(28,29)}$.

The low consumption of fruits and vegetables, a monotonous diet, and the presence of junk foods or ultra-processed foods may explain part of the high prevalence of micronutrient inadequacy observed ${ }^{(5,41,42)}$. Clearly, limiting the explanation of inadequate food consumption and the consequent high prevalence of micronutrient inadequacy to a restricted economic access is not correct, as the inadequacy also appears in the quartile with less risk of SFI. The influence of finances on the consumption of food sources with vitamins and minerals is already known ${ }^{(43,44)}$, but other factors may also be considered in this dynamic, such as the presence of food deserts or swamps ${ }^{(34,35,45)}$. An intervention study, which distributed vouchers for fruits and vegetables to a poverty-stricken population participating in a social assistance programme, observed increased purchases of these foods only when physical access to establishments that sold them was also facilitated ${ }^{(46)}$.

$\mathrm{Na}$ intake among Brazilians is very high ${ }^{(30)}$, and our study illustrated this. Intake above the UL was observed in the two groups analysed. In Brazil, much of the $\mathrm{Na}$ available for consumption comes mainly from cooking salt and salt-based condiments; however, the share of processed food with added salt has increased in the Brazilian diet ${ }^{(30)}$. It is known that excessive intake of this nutrient produces adverse health consequences favouring the emergence of hypertension ${ }^{(47)}$. Among individuals experiencing FI, high Na intake can maximize potential harm, as these individuals generally have a lower consumption of potentially protective foods and limited access to health services, which makes proper treatment difficult ${ }^{(10,48)}$.

The high prevalences of inadequate nutrient intakes may lead to nutritional deficiencies with important repercussions on individuals' health. In addition to FI, inadequate nutrient intake is associated with negative health consequences such as anaemia and cognitive problems in children, as well as obesity, diabetes, hypertension and dyslipidaemia in adults ${ }^{(10,49,50)}$. In addition to the repercussions on health, hidden hunger (lack of vitamins and minerals) also has important social and economic consequences, contributing to the perpetuation of the vicious cycle of poverty and malnutrition, reducing individuals' productive capacity, minimizing their chances of migrating to a more favourable living condition, generating costs for the health system and limiting the country's economic growth ${ }^{(15,51)}$.

Clearly, the best strategy for adjusting the food consumption of a population at risk of SFI would be to reduce their FI. Brazil has made great progress in improving this situation over the last decades. Economic growth coupled with policies that prioritize social services, including cash transfers to people living in situations of extreme poverty ${ }^{(52)}$, were important factors for coping with hunger. Cash transfer programmes, such as the Bolsa Familia in Brazil, are used in several countries to improve access to food, with a positive impact on improving food security and its consequences $^{(10,11,53,54)}$. This set of actions contributed to the removal of Brazil from the UN Hunger Map in $2015^{(11)}$. However, all these achievements are threatened by the political instability that Brazil has experienced in recent years, marked mainly by fiscal austerity measures, with budget cuts, including to assistance programmes, which can aggravate the main social problems in the country ${ }^{(55,56)}$. An example of the effects of this economic crisis is the infant mortality rate, which recently increased for the first time since 1990, and with continued growth being expected if the level of social services continues to decline ${ }^{(55,57)}$.

In addition to coping strategies for FI, some tools can also be used to specifically fight against nutritional deficiencies. In Brazil, wheat and maize flour (low-cost and largely consumed foods) are required to be fortified with Fe and folic acid ${ }^{(58,59)}$ but the impact of this intervention in Brazil and other low-income countries is limited ${ }^{(60)}$. There are also Fe and vitamin A supplement programmes ${ }^{(38,58)}$, but this intervention in Brazil is addressed only for the population at risk (women and children). Food fortification and micronutrient supplementation programmes could be reinforced and maybe expanded to address people below the poverty line as a short- and medium-term intervention for hidden hunger reduction ${ }^{(17,37)}$. Other interventions could be considered such as options that improve fruit and vegetable consumption. Encouragement of family/community gardens, as well as food and nutrition education, are also useful tools in the fight against nutritional deficiencies in low-income populations ${ }^{(37,61)}$.

The present study has some limitations in the comparability of the results that should be considered. A limited number of variables were used to construct the predictive model of SFI, since these had to be present in the two databases used. However, in the absence of a direct indicator of food security ${ }^{(62)}$, this model has the advantage of capturing the phenomenon using a greater number of variables associated with FI besides only income. This allowed our study to predict the risk of individual FI from household FI. Another limitation is the use of the EAR as a cut-off point, because this nutritional reference parameter was established for the North American and Canadian population; however, there are no reference values for average nutrient requirements based on studies with Brazilians. 


\section{Conclusions}

The food consumption of the Brazilian population at risk of SFI (Q4) is characterized by energy reduction, reflecting lower intakes of macronutrients, as well as a high prevalence of inadequate intakes of vitamins and minerals when compared with the portion of the population with lower risk of SFI (Q1). There is a clear need for investment in new strategies and the strengthening of existing actions in the country to guarantee physical and financial access to a quality diet, to protect the more vulnerable population from the consequences of a poor diet. More research is also needed to jointly assess the condition of food security and food consumption of the Brazilian population.

\section{Acknowledgements}

Acknowledgements: The authors thank A. Gaspar Sousa, A. de Moura Souza and E. Verly Junior, who contributed to the statistical analysis of the data. Financial support: This work was financed by the National Council for Scientific and Technological Development (CNPq; grant number 409165/2016-6). CNPq had no participation in the design, analysis or writing of the article. A Coordination for the Improvement of Higher Education Personnel, Ministry of Education (CAPES) doctorate scholarship was granted to S.E.A.C.K. and partial support with Finance code 001. Conflict of interest: The authors declare no conflicts of interest. Authorship: S.E.A.C.K. and M.B.G. contributed to the conception and design of the study, statistical analysis, data interpretation, writing and review of the article. T.H.M.C. participated in the interpretation of the data and critical review of the article. All authors reviewed and approved the final version. Ethics of buman subject participation: In Brazil, according to Resolution No. 510 of the National Health Council (7 April 2016), research with public domain databases whose information is aggregated, without the possibility of individual identification, does not need to be registered or evaluated by the ethics in research.

\section{Supplementary material}

To view supplementary material for this article, please visit https://doi.org/10.1017/S1368980019003057

\section{References}

1. Food and Agriculture Organization of the United Nations (1996) Declaration on World Food Security and World Food Summit Plan of Action. Rome: FAO.

2. Hanson KL \& Connor LM (2014) Food insecurity and dietary quality in US adults and children: a systematic review. Am J Clin Nutr 100, 684-692.
3. Bocquier A, Vieux F, Lioret S et al. (2015) Socio-economic characteristics, living conditions and diet quality are associated with food insecurity in France. Public Health Nutr 18, 2952-2961.

4. Rodríguez LA, Mundo-Rosas V, Méndez-Gómez-Humarán I et al. (2016) Dietary quality and household food insecurity among Mexican children and adolescents. Matern Child Nutr 13, 1-12.

5. Leung CW, Epel ES \& Ritchie LD (2014) Food insecurity is inversely associated with diet quality of lower-income adults. J Acad Nutr Diet 114, 1943-1953.

6. Russell JC, Flood VM, Yeatman H et al. (2016) Food insecurity and poor diet quality are associated with reduced quality of life in older adults. Nutr Diet 73, 50-58.

7. Laraia BA (2013) Food insecurity and chronic disease. Adv Nutr 4, 203-212.

8. Tarasuk V, Mitchell A \& McLaren L (2013) Chronic physical and mental health conditions among adults may increase vulnerability to household food insecurity. J Nutr $\mathbf{1 4 3}$, $1785-1793$.

9. Vedovato GM, Surkan PJ, Jones-Smith J et al. (2016) Food insecurity, overweight and obesity among low-income African-American families in Baltimore City: associations with food-related perceptions. Public Health Nutr 19, 1405-1416.

10. Gundersen C \& Ziliak JP (2015) Food insecurity and health outcomes. Health Aff (Millwood) 34, 1830-1839.

11. Food and Agriculture Organization of the United Nations Brazil (2015) O Estado da Segurança Alimentar $e$ Nutricional no Brasil - Agendas Convergentes (SOFI Brasil). Brazil: FAO.

12. Gubert MB, Spaniol AM, Segall-Corrêa AM et al. (2017) Understanding the double burden of malnutrition in food insecure households in Brazil. Mater Child Nutr 13, e12347.

13. Martins APB, Levy RB, Claro RM et al. (2013) Participação crescente de produtos ultraprocessados na dieta brasileira (1987-2009). Rev Saude Publica 47, 656-665.

14. Morais SC, Dutra LV, Franceschini SCC et al. (2014) Food insecurity and anthropometric, dietary and social indicators in Brazilian studies: a systematic review. Cienc Saude Colet 19, 1475-1488.

15. Von Grebmer K, Saltzman A, Birol E et al. (2014) 2014 Global Hunger Index: The Challenge of Hidden Hunger. Washington, DC: International Food Policy Research Institute; available at http://www.ifpri.org/sites/default/ files/publications/ghi14.pdf (accessed September 2018).

16. Food and Agriculture Organization of the United Nations (2015) The State of Food Insecurity in the World. Meeting the 2015 International Hunger Targets: Taking Stock of Uneven Progress. Rome: FAO.

17. Gödecke T, Stein AJ \& Qaim M (2018) The global burden of chronic and hidden hunger: trends and determinants. Glob Food Sec 17, 21-29.

18. Instituto Brasileiro de Geografia e Estatística (2010) Pesquisa de Orçamentos Familiares (POF) 2008-2009. Análise do Consumo Alimentar Pessoal no Brasil. Rio de Janeiro, RJ: IBGE; available at https://biblioteca.ibge.gov.br/visualizacao/ livros/liv50063.pdf (accessed September 2018).

19. Instituto Brasileiro de Geografia e Estatística (2010) Pesquisa Nacional por Amostra de Domicílios - PNAD. Segurança Alimentar, 2004/2009. Rio de Janeiro, RJ: IBGE; available at https://biblioteca.ibge.gov.br/visualizacao/livros/liv 472 41.pdf (accessed September 2018).

20. Gubert MB, Benicio MHD, da Silva JP et al. (2010) Use of a predictive model for food insecurity estimates in Brazil. Arch Latinoam Nutr 60, 119-125.

21. Gubert MB, Santos SMC, Santos LMP et al. (2017) A municipal-level analysis of secular trends in severe food insecurity in Brazil between 2004 and 2013. Glob Food Sec 14, 61-67. 
22. Nagelkerke NJD (1991) A note on the general definition of the coefficient of determination. Biometrika $\mathbf{7 8}$, 691-692.

23. Zweig MH \& Campbell G (1993) Receiver-operating characteristic (ROC) plots. Clin Chem 29, 561-577.

24. Instituto Brasileiro de Geografia e Estatística (2011) Pesquisa de Orçamentos Familiares 2008-2009: Tabela de Composição Nutricional dos Alimentos Consumidos no Brasil. Rio de Janeiro, RJ: IBGE; available at https://biblioteca.ibge.gov.br/ visualizacao/livros/liv50002.pdf (accessed September 2018).

25. Instituto Brasileiro de Geografia e Estatística (2011) Pesquisa de Orçamentos Familiares 2008-2009: Tabela de Medidas Referidas para os Alimentos Consumidos no Brasil. Rio de Janeiro, RJ: IBGE; available at https://biblioteca.ibge.gov. br/visualizacao/livros/liv50000.pdf (accessed September 2018).

26. Tooze JA, Midthune D, Dodd KW et al. (2006) A new statistical method for estimating the usual intake of episodically consumed foods with application to their distribution. J Am Diet Assoc 106, 1575-1587.

27. Barbosa FS, Sichieri R \& Junger WL (2013) Assessing usual dietary intake in complex sample design surveys: the National Dietary Survey. Rev Saude Publica 47, Suppl. 1, 171S-176S.

28. Institute of Medicine, Standing Committee on the Scientific Evaluation of Dietary Reference Intakes (2000) Dietary Reference Intakes: Applications in Dietary Assessment. Washington, DC: National Academies Press; available at https://www.nap.edu/catalog/9956/dietary-reference-intak es-applications-in-dietary-assessment (accessed April 2018).

29. Institute of Medicine (2011) Dietary Reference Intakes for Calcium and Vitamin D. Washington, DC: National Academies Press; available at https://www.nap.edu/catalog/ 13050/dietary-reference-intakes-for-calcium-and-vitamin-d (accessed April 2018).

30. Sarno F, Claro RM, Levy RB et al. (2013) Estimativa de consumo de sódio pela população brasileira, 2008-2009. Rev Saude Publica $\mathbf{4 7}, 571-578$.

31. Institute of Medicine (2001) Dietary Reference Intakes for Vitamin A, Vitamin K, Arsenic, Boron, Chromium, Copper, Iodine, Iron, Manganese, Molybdenum, Nickel, Silicon, Vanadium, and Zinc. Washington, DC: National Academies Press.

32. Frozi DS, Sichieri R, Santos SMC et al. (2015) Characteristics of social vulnerability and food insecurity among urban families in extreme poverty in Brazil. J Food Secur 3, 62-68.

33. Darmon N \& Drewnowski A (2015) Contribution of food prices and diet cost to socioeconomic disparities in diet quality and health: a systematic review and analysis. Nutr Rev 73, 643-660.

34. Walker RE, Keane CR \& Burke JG (2010) Disparities and access to healthy food in the United States: a review of food deserts literature. Health Place 16, 876-884.

35. Pessoa MC, Mendes LL, Gomes CS et al. (2015) Food environment and fruit and vegetable intake in a urban population: a multilevel analysis. BMC Public Health 15, 1012.

36. Farrell P, Thow AM, Abimbola S et al. (2017) How food insecurity could lead to obesity in LMICs. When not enough is too much: a realist review of how food insecurity could lead to obesity in low- and middle-income countries. Health Promot Int 33, 812-826.

37. Beal T, Massiot E, Arsenault JE et al. (2017) Global trends in dietary micronutrients supplies and estimated prevalence of inadequate intakes. PLOS One 12, e0175554.

38. Ministério da Saúde (2013) Programa Nacional de Suplementação de Vitamina A. Manual de Condutas Gerais. Brasília, DF: MS; available at http://bvsms.saude. gov.br/bvs/publicacoes/manual_condutas_suplementacao_ vitamina_a.pdf (accessed May 2018).
39. Soares JC (2018) Composição fenólica e atividade biológica in vitro e in vivo de frutas nativas brasileiras. Doctoral Dissertation, Universidade de São Paulo.

40. Jones AD, Mundo-Rosas V, Cantoral A et al. (2017) Household food insecurity in Mexico is associated with the co-occurrence of overweight and anemia among women of reproductive age, but not female adolescents. Matern Child Nutr 13, e12396.

41. Coelho SEAC (2018) Consumo alimentar da população em risco de insegurança alimentar grave no Brasil. Doctoral Dissertation, Universidade de Brasília.

42. Kim HJ \& Oh K (2015) Household food insecurity and dietary intake in Korea: results from the 2012 Korea National Health and Nutrition Examination Survey. Public Health Nutr 18, $3317-3325$.

43. Hassen WS, Castetbon K, Cardon P et al. (2016) Socioeconomic indicators are independently associated with nutrient intake in French adults: a DEDIPAC study. Nutrients 8, 158.

44. Bailey RL, Akabas SR, Paxson EE et al. (2017) Total usual intake of shortfall nutrients varies with poverty among US adults. J Nutr Educ Behav 49, 639-646.e3.

45. Luan H, Law J \& Quick M (2015) Identifying food deserts and swamps based on relative healthy food access: a spatio-temporal Bayesian approach. Int J Health Geogr $14,37$.

46. Okeke JO, Ekanayake RM \& Santorelli ML (2017) Effects of a 2014 statewide policy change on cash-value voucher redemptions for fruits/vegetables among participants in the supplemental nutrition program for Women, Infants, and Children (WIC). Matern Child Health J 21, 1874.

47. Whelton PK, Carey RM, Aronow WS et al. (2018) ACC/ AHA/AAPA/ABC/ACPM/AGS/APhA/ASH/ASPC/NMA/PCNA Guideline for the Prevention, Detection, Evaluation, and Management of High Blood Pressure in Adults. J Am Coll Cardiol 71, e127-e248.

48. Pérez-Escamilla R, Villalpando S, Shamah-Levy T et al. (2014) Household food insecurity, diabetes and hypertension among Mexican adults: results from ENSANUT-2012. Salud Publica Mex 56, Suppl. 1, S62-S70.

49. Ke J \& Ford-Jones EL (2015) Food insecurity and hunger: A review of the effects on children's health and behaviour. Paediatr Child Health 20, 89-91.

50. Dhurandhar EJ (2016) The food-insecurity obesity paradox: a resource scarcity hypothesis. Physiol Behav 162, 88-92.

51. Ruel-Bergeron JC, Stevens GA, Sugimoto JD et al. (2015) Global update and trends of hidden hunger, 1995-2011: the Hidden Hunger Index. PLoS One 10, e0143497.

52. Campello T \& Côrtes Neri M (2014) Bolsa Familia Program: A Decade of Social Inclusion in Brazil. Executive Summary. Brasilia, DF: Institute for Applied Economic Research; available at http://www.ipea.gov.br/portal/images/stories/PDFs /140321_pbf_sumex_ingles.pdf (accessed July 2018).

53. Duffy PA \& Zizza CA (2016) Food insecurity and programs to alleviate it: what we know and what we have yet to learn. J Agric Appl Econ 48, 1-28.

54. Segura-Pérez S, Grajeda R \& Pérez-Escamilla R (2016) Conditional cash transfer programs and the health and nutrition of Latin American children. Rev Panam Salud Publica 40, 124-137.

55. Rasella D, Basu S, Hone T et al. (2018) Child morbidity and mortality associated with alternative policy responses to the economic crisis in Brazil: a nationwide microsimulation study. PLoS Med 15, e1002570.

56. Oliveira ALM, Dweck E \& Rossi P (2018) Economia para Poucos - Impactos Sociais da Austeridade e Alternativas para o Brasil. Brasília, DF: Editora Autonomia Literária.

57. Ministério da Saúde (2018) DATASUS: informações de saúde (TABNET). http://tabnet.datasus.gov.br/ (accessed July 2018). 
58. Ministério da Saúde (2007) Cadernos de Atenção Básica $n^{\circ}$ 20. Carências de Micronutrientes. Brasília, DF: MS; available at http://189.28.128.100/dab/docs/publicacoes/ cadernos_ab/abcad20.pdf (accessed July 2018).

59. Ministério da Saúde (2013) Programa Nacional de Suplementação de Ferro. Manual de Condutas Gerais. Brasília, DF: MS; available at http://bvsms.saude.gov.br/ bvs/publicacoes/manual_suplementacao_ferro_condutas_ gerais.pdf (accessed May 2018).

60. Keats EC, Neufeld LM, Garrett GS et al. (2019) Improved micronutrient status and health outcomes in low- and middle-income countries following large-scale fortification: evidence from a systematic review and meta-analysis. Am J Clin Nutr 109, 1696-1708.

61. Pandey VL, Dev SM \& Jayachandran U (2016) Impact of agricultural interventions on the nutritional status in South Asia: a review. Food Policy 62, 28-40.

62. Pérez-Escamilla R, Gubert MB, Rogers B et al. (2017) Food security measurement and governance: assessment of the usefulness of diverse food insecurity indicators for policy makers. Glob Food Sec 14, 96-104. 